\title{
Alternate Possibilities, Divine Omniscience and Critique of Judgement $\$ 76$
}

\author{
Kimberly Brewer \\ Indiana University Bloomington \\ Email: kimbbrew@iu.edu
}

\begin{abstract}
A philosophically and historically influential section of the Critique of Judgement presents an 'intuitive intellect' as a mind whose representation is limited to what actually exists, and does not extend to mere possibilities. Kant's paradigmatic instance of such an intellect is however also the divine mind. This combination threatens to rule out the reality of the mere possibilities presupposed by Kant's theory of human freedom. Through an analysis of the relevant issues in metaphysical cosmology, modal metaphysics and philosophical theology, I show that Kant in fact possesses the resources to reconcile the philosophical claims of $\$ 76$ of the Critique of Judgement with his keystone commitment to the reality of human freedom.
\end{abstract}

Keywords: Kant; intuitive intellect; modal metaphysics; divine omniscience; freedom

Perhaps never in so few pages have so many deep thoughts been crowded together as in $\$ 76$ of the Critique of Teleological Judgement. (Schelling, Vom Ich als Prinzip der Philosophie)

\section{Introduction}

Schelling's sentiment seems to have been widely shared by the post-Kantian German idealists, a number of whom famously appropriated some version of these 'deep thoughts' into their own philosophical systems. The influence of $\$ 76$ of the Critique of Judgement on Kant's successors has been well canvassed in the literature (see e.g. Sedgwick 2000, Förster 2012). Much less discussed, although certainly no less important, is the problem that this section apparently poses for Kant's own philosophical commitments - most notably, for his commitment to human freedom. The present essay offers a discussion of this problem as well as a new attempt to resolve it.

What if John Wilkes Booth's derringer had jammed? What if Hitler had been accepted into art school? We often imagine alternative ways the world could be. Kant tells us in $K U \$ 76^{1}$ that this capacity for modal thought is in fact an 'absolutely necessary' feature of the human mind $(5: 401){ }^{2}$ Yet in the same section, he also 
describes a kind of mind very different from our own that would represent the world only as it actually is. More precisely, we are told that this 'intuitive intellect' would represent 'no objects except what is actual' and 'no such distinction (between the possible and the actual)':

[A]ll objects that [it] cognize[s] would be (exist), and the possibility of some that did not exist, i.e., their contingency if they did exist, as well as the necessity that is to be distinguished from that, would not enter into the representation of such a being at all. (5: 402-3; cf. Reflexion 6020, 18: 425-6)

Read straightforwardly, this passage expresses the claim that an intuitive intellect would not represent mere possibilities. What seems to follow from this, as we will see below, is the exclusion of mere possibilities and with this the exclusion of human freedom as Kant conceives of it. For given his commitment to the intuitive character of God's intellect, ${ }^{3} \mathrm{KU} \$ 76$ has the immediate consequence that God does not represent mere possibilities. Yet if the being regarded both as the ultimate ground of possibility and as omniscient does not represent mere possibilities, the conclusion is near at hand that there are no such possibilities - a profoundly unwelcome implication given Kant's commitment to carving out logical space for a conception of human freedom that presupposes mere possibilities. ${ }^{4}$ In particular, Kant holds that the reality of moral obligations "presupposes that although something has not happened, it nevertheless ought to have happened' (A534/B562), and furthermore that this 'ought' implies 'can' such that this something could have happened (A555/B583). Relative to the course of the actual world, alternatives to moral failures are of course mere possibilities. The problem is then that such possibilities threaten to be excluded outright by Kant's characterization of God's mind as not representing these possibilities. The sympathetic reader is thus confronted with a challenge: Can human freedom, as Kant understands it, be reconciled with the conception of the divine mind set out in $K U \$ 76 ?^{5}$

In this article, I will argue that Kant can deny the implication that there would be no mere possibilities if the divine intuitive intellect does not represent them. This generates two tasks. In the next section, I argue that the mere possibilities presupposed by Kant's conception of freedom may for our purposes be treated as possible worlds - worlds in which an agent's character is other than it actually is. ${ }^{6}$ Now the dominant view in eighteenth-century German philosophy is that worlds are possible only insofar as God represents them. ${ }^{7}$ I must therefore show that Kant can furnish an alternative metaphysics of mere possibility, one that does not appeal to divine representation. The problem posed by $K U \$ 76$ is however amplified by the theological doctrine of divine omniscience and in particular by the thought that this doctrine renders impossible whatever God does not represent: if God does not represent mere possibilities, it seems to follow that there are no such possibilities. Any attempt that seeks to solve the problem by simply relinquishing divine omniscience would of course collide with Kant's explicit theological pronouncements (cf. A815/B843; $\mathrm{KpV}$, 5: 140; KU, 5: 444). I must therefore also show that my solution is consistent with Kant's commitment to divine omniscience.

I will begin by clarifying the philosophical problem presented by KU \$76 (section 2). I then consider and reject two alternative solutions (section 3). Finally, I present and defend my own solution. Its central idea is that Kant can account for mere possibility 
without appealing to divine representation (section 4) and without violating his commitment to divine omniscience (section 5). I close by responding to three significant objections (section 6).

\section{The problem}

To the end of clarifying the problem at issue in $K U ~ § 76$, it is necessary to explain what kind of mere possibilities human freedom presupposes. It is widely acknowledged in what is an active area of Kant scholarship that his modal theory is complex and involves several kinds of possibility (see e.g. Stang 2016, Abaci 2019). If we are to determine whether he has resources to carve out space for the mere possibilities presupposed by human freedom, we must be clear about which kind of possibilities these are. To this end, it will suffice to focus on his notions of logical and real possibility.

Logical possibility is a familiar notion. An object is logically possible if its concept is possible in the sense of involving no contradiction. Real possibility is less familiar. It is comparable to the contemporary notion of metaphysical possibility. ${ }^{8}$ An object is really possible if its existence is possible. For Kant, these notions come apart; he insists that not everything logically possible is also really possible. Consider the stock example of the Postulates chapter: 'a figure that is enclosed between two straight lines' (A220/B268). This figure is presented as logically possible because its concept does not contain a contradiction. Yet the figure fails to be really possible given 'conditions of space' constraining empirical existence (A221/B268).

Which kind of mere possibility is presupposed by human freedom on Kant's view? Logical possibility or also real? I suggest his answer is most plausibly the latter. Mere logical possibilities are too weak for the incompatibilist conception of freedom he is concerned to make room for; indeed even during his early compatibilist phase Kant scornfully dismisses the Leibniz-Wolffian position that the mere logical possibility of non-actual alternatives suffices to 'diminish the force of the necessity or the certainty of the determination' of our actions (ND, 1: 400). It would be hard to argue that he changed his mind on this elementary point subsequent to his own conversion to incompatibilism. If that is right, then when he tells us that human freedom 'presupposes that although something has not happened, it nevertheless ought to have happened' (A534/B562), his commitment to ought-implies-can entails that the 'something' that ought to have happened really could have happened; it is a real possibility. ${ }^{9}$

Given Kant's idealism, however, we have not yet adequately answered our question regarding the possibility presupposed by human freedom. For his idealism brings with it a further distinction within the notion of real possibility - the distinction between real possibility relative to appearances (reality as experienced by discursive beings like us) and real possibility relative to things in themselves (reality as it is independently of our experience of it). It will suffice for present purposes to say that an object is really possible relative to appearances if it could exist in the world of appearances, and really possible relative to things in themselves if it could exist in the world of things in themselves. ${ }^{10}$ Like logical and real possibility, these notions come apart, this time in both directions. This is due in part to the fact that appearances are spatial and temporal, while Kant insists that things in themselves are not (A26/B42, A32-3/B49). The conditions on what exists in each world consequently differ. For example, 
temporal objects are really possible in the world of appearances but not in the world of things in themselves, while non-temporal objects are really possible in the world of things in themselves but not in the world of appearances.

So which kind of mere real possibility is presupposed by human freedom? Real possibility relative to appearances or real possibility relative to things in themselves? The answer for Kant is evidently both, but most fundamentally the latter. Recall his famous case of the 'malicious lie' (A554/B582). Kant explains that an agent is free and hence also blameworthy with respect to this lie not more fundamentally in virtue of an 'empirical character' but rather an 'intelligible character'. As he explains, 'another intelligible character would have given another empirical [character]', and so another action (A556/B584). An agent is ultimately blameworthy, then, not in virtue of his or her character in the world of appearances (e.g. 'the wickedness of a natural temper insensitive to shame') but in virtue of a character in the world of things in themselves that prioritizes either morality or self-love (A554/B582; cf. Religion, 6: 31-2). It is ultimately the latter that Kant argues 'could have and ought to have determined the conduct of the person to be other than it is' (A555/B583). Thus, the fundamental ground of the 'something that has not happened [but] ought to have happened' is located at the level of the agent's character in the world of things in themselves (A534/B562).

Human freedom, as Kant conceives of it, thus presupposes real mere possibilities relative to things in themselves. It presupposes the real possibility of non-actual worlds at the level of things in themselves, worlds in which an agent's intelligible character is other than it actually is. Whether Kant has the resources to carve out logical space for human freedom thus depends on whether he can carve out space for such mere possibility. Let me put this point another way: there are conditions that must obtain for worlds to be able to exist, i.e. to be really possible; the question to be addressed is whether $K U § 76$ 's conception of God's intellect is logically consistent with these existential conditions, thus with human freedom. Is the real possibility of non-actualized worlds consistent with a Kantian God who does not represent such worlds and yet is regarded both as real possibility's ultimate ground and as omniscient?

I will argue that Kant's writings contain resources for an affirmative answer to this question. My argument consists of two parts. In section 4, I offer a reading of Kant's modal metaphysics that does not rest the possibilities demanded by freedom on divine representation. The imputed account diverges significantly from eighteenth-century German orthodoxy regarding modality, insofar as major predecessors including Leibniz, Wolff and Baumgarten agree that worlds are possible if and only if God represents them. ${ }^{11}$ The second part of my argument, in section 5, tackles the seemingly intractable challenge to freedom that arises as soon as God's omniscience is paired with $K U$ §76's account of divine representation. Regardless of his metaphysics of modality, how can Kant consistently affirm real possibilities not represented by an omniscient God? The answer I will advance involves a very radical departure from received interpretations of Kant's philosophical theology. It nevertheless remains remarkably consistent with his own presentation of his theology across the gamut of Critical texts, while solving the seemingly intractable problem at hand. I will not insist that Kant must be read as endorsing my proposal; I will however defend the claim that it must count as a live candidate for his position, notwithstanding its distance from theological orthodoxy. 


\section{Two rejected alternatives}

Before turning to my proposed solution, it will be helpful motivation to begin by briefly explaining why two tempting alternative solutions are unsatisfying. The first draws attention to KU's claim that an intuitive intellect represents neither mere possibility nor necessity: 'necessity ... would not enter into the representation of such a being' (5: 403). If God is omniscient, represents reality as it is and does not represent necessity, it seems to follow that there is no necessity relative to things in themselves. Thus, even if $K U \$ 76$ did rule out mere possibilities, so this suggestion goes, this will not imply the necessity of our actions.

This solution is unsatisfying for two reasons. First and foremost, whether or not things in themselves are free from necessity, human freedom as Kant explicates it demands mere possibilities, and so remains in jeopardy. If his motivation for preserving such possibilities were only a concern about necessitation, then indeed the exclusion of real possibility would not threaten freedom so long as necessity were also excluded. But as the first Critique famously explains, his motivation is based on the fundamental principle that ought implies can (A555/B583; cf. Religion, 6: 45). In the absence of moral perfection, this requirement is threatened as much by the exclusion of mere possibility as by necessitation. ${ }^{12}$ The second reason this proposal is unsatisfying has to do with its implied 'noumenal amodalism', that is, its suggestion that Kant means to exclude both necessity and possibility relative to things in themselves. In fact, Kant consistently characterizes God's existence as necessary; indeed, a famous remark at A613/B641 describes this necessity as the 'true abyss' for human and divine understandings. His resolution of the fourth antinomy insists that its thesis, that 'there must exist something absolutely necessary', may be true of things in themselves (A452/B480, A532-3/B560-1). He also consistently writes of God's will that no imperatives apply to it because its 'volition is of itself necessarily in accord with the law' (GMS, 4: 414; cf. 4: 439; V-Phil-Th/Pölitz, 28: 1068). ${ }^{13}$

A second alternative solution claims that, even if Kant's preferred account of divine representation entails the exclusion of mere possibility, we are off the hook with respect to effecting a reconciliation with freedom because, given Critical strictures, we cannot know such exclusion obtains. The main problem with this proposal is that it threatens to run afoul of a central aim of the Critical philosophy - that of 'making room for belief/faith (Glaube)' in God and freedom (Bxxx). It is hard to see how Kant accommodates these beliefs if they conflict. This is of course not to say he must show precisely how these beliefs fit together. Indeed, his Religion does not regard the 'impenetrable mystery' involved in the related combination of divine creation and absolute spontaneity as an insurmountable obstacle to our belief (6:143). Notice however that what we are faced with in $K U \$ 76$ appears less like an impenetrable mystery and more like a case of penetrable inconsistency, and it is unlikely that Kant will be satisfied with that. For even in the case of absolute spontaneity and divine creation, he does not settle for inconsistency, as evident by the second Critique's attempt to reconcile the two (5: 100-3; cf. Franks 2005: ch. 2, Brewer and Watkins 2012). At the very least, I would argue, it is infinitely preferable given Kant's general distaste for fideism and all flavours of irrationalism to offer a real philosophical solution here rather than simply surrender to mysterianism. 


\section{Unrepresented possibles}

I turn in this section to the proposal I will develop and defend in the remainder of this article. I argue that, even if $K U$ \$76 entails that God does not represent mere possibles, Kant is not forced to conclude that no such possibilities exist. My argument has two parts, respectively addressing his metaphysical grounding of real possibility (section 4), and the seemingly intractable problem $K U$ §76 poses for mere possibles in light of divine omniscience (section 5). I will show that Kant's writings furnish all the ingredients for a metaphysics of modality permitting the grounding of mere possibles that are not represented by God. I turn now to the development of that theory.

\section{I The ground of possibility}

Kant's early writings defend a version of modal actualism, the view that what is possible must have its ground in something existent or actual. Kant also argues that God's existence must be posited as the ultimate ground of possibility; the locus classicus of his modal actualism is the theistic proof of his 1763 Only Possible Argument essay. That proof sets out from the weak premise that 'something is possible' (2: 91). It proceeds to argue, first, that such possibility requires fulfilment of a formal and material condition; second, that the material condition demands that the ens realissimum exist. The first Critique's attack on speculative theology denies that the early theistic proof from possibility can furnish the promised demonstration of God's existence. Kant retains sympathy for the proof, however, and transcripts from the Critical period assert that it 'can in no way be refuted' (V-Phil-Th/Pölitz, 28: 1034). According to Critical doctrine, the argument cannot ground knowledge that God exists, but it does establish the 'subjective necessity of assuming such a being' (28: 1034; cf. A580/B608, A582-3/B660-1). It hardly needs reminding that Kant's mature critique of speculative theology does not dogmatically reject his early conclusion that God exists; this remains the central tenet of the moral theology he puts in its place. Nor does Kant dogmatically challenge his early actualist model of possibility in general. ${ }^{14}$ The Postulates chapter of the first Critique also argues for a version of modal actualism for the domain of empirical possibility. ${ }^{15}$

How does the metaphysical grounding of possibility work on Kant's early model? Consider his example of a fiery body. He explains that the possibility of such a body is not grounded merely by satisfying the formal condition that its predicates contain no contradiction. It is also necessary that the material content of these predicates ('extension, impenetrability, force, and I know not what else') is 'given in something actual, either as a determination existing within it or as a consequence arising from it' (BDG, 2: 79-80). For, as Kant argues, 'possibility disappears not only when an internal contradiction, the logical element of impossibility, is present, but also when there exists no material element, no datum, to be thought' (2: 78). He goes on to argue in detail that this material condition is ultimately met only by the existence of the ens realissimum:

The data of all possibility must be found in the necessary being either as determinations of it, or as consequences which are given through the necessary being as the ultimate real ground. ... [A]ll reality is, in one way or another, embraced by the ultimate real ground. ... Such a being is, therefore, the most real of all possible beings. (2: 85 ) 
In sum, Kant's early metaphysics of possibility in general maintains that the material content from which all possibility is constructed is given by the ens realissimum 'as determinations of it, or as consequences given through [it]'. Adams and Chignell have developed versions of what is now the dominant interpretation of this modal theory. Both read Kant as arguing that the material content from which all possibility is constructed is given by the ens realissimum in virtue of it exemplifying 'not all possibilities, but the most fundamental qualitative possibilities' (Adams 2000: 427). As Chignell (2009: 158) has it, God 'exemplifies a maximal version of every fundamental positive predicate or "reality", from which all positive, negative, limited and complex predicates can be constructed. Thus, where $F$ is a fundamental positive predicate or reality, the ens realissimum grounds the possibility of $F$, the negation of $F$, degrees of $F$ and composites of $F$ and other predicates by exemplifying the most metaphysically robust version of $F$. By exemplifying omnipotence, for instance, the ens realissimum grounds the possibility of power, powerlessness, degrees of power and powerful entities. ${ }^{16}$

\subsection{The ground of the actual world}

Kant's account of God's grounding of the actual world, a version of which remains central to his mature philosophy, builds on his early account of possibility. PreCritical works argue that a world is a whole of substances that stand in real and reciprocal causal relations to one another (e.g. MSI, 2: 389-91) - where such relations do not obtain simply in virtue of the existence of these substances but in virtue of 'a communality of a cause', namely God (ND, 1: 413). ${ }^{17}$ Specifically, Kant argues that the 'schema of the divine understanding, which gives existence', must also establish 'the relations of things to each other, by conceiving their existence as correlated with one another'. The metaphysical ground of the actual world is thus located in divine representation. ${ }^{18}$ God represents substances as causally related, and through this representation God 'gives existence' both to substances and to their relations. The possibility of actual substances is in turn grounded by the maximal and fundamental realities that God exemplifies.

It will be useful to distinguish two sets of real relations in Kant's account, which I call the 'internal' and 'external' relations of finite substances. The former refers to relations between realities in an individual substance (e.g. the coexistence of will and understanding), while the latter refers to relations between substances. Though Kant does not explicitly thematize the former, he is committed to the view that divine representation also 'gives them existence'. His theory of the grounding of actual substances and their actual relations may then be summarized as follows. The ground of the actuality of a substance is in a certain respect analogous to that of an actual world. Just as the actual world is grounded by God's representation of substances as standing in external relations (which Kant claims includes causal interdependence), an actual individual substance is grounded by God's representation of its realities standing in internal relations (ND, 1: 412-14; MSI, 2: 407-8). I will return to this distinction below, but I focus first on the issue of external relations.

Let us sharpen our focus on how Kant's models of possibility and of actuality fit together. To this end, consider as a simple analogy a 'deity' who is the 'ens realissimum' with respect to all possible desserts. Let us say that this deity grounds an actual chocolate chip cookie by representing and thereby also giving existence to the appropriate 
mixture of ingredients; the flour, butter, chocolate chips and so on. The possibility of these ingredients is in turn grounded by the maximal and fundamental ingredients the deity exemplifies - a 'maximal' version of the wheat that goes into the flour, the cocoa that goes into the chips, etc. This deity's representation gives existence both to the ingredients and to the actual mixture that it represents. We must also ask, however, what grounds the merely possible cookies, brownies, cupcakes and so on? In particular, what is the ground of their merely possible mixtures of ingredients?

We seek, analogously, the ground of merely possible worlds for Kant, insofar as these are presupposed by his theory of human freedom. While the Critical philosophy offers an explicit theory of God's grounding of the actuality of things in themselves through his creative representation, ${ }^{19}$ it has little to say on the grounding of possible worlds of things in themselves. In what follows, I develop a theory suggested by Kant's models of possibility and actuality, one that is consistent with $K U$ §76's suggestion that God does not represent merely possible worlds.

\subsection{The ground of merely possible worlds}

The model I will propose sets out from Kant's own model of a world as a whole whose elements stand in real reciprocal causal relations. An actual world of things in themselves will then be a whole of actual things in themselves which stand in actual reciprocal causal relations. A possible world of things in themselves will be a whole of possible things in themselves in merely possible causal relations. I have summarized Kant's basic theistic model of an actual world both as regards its possibility and its existence. The possibility of things constituting an actual world is grounded by the realities exemplified by the ens realissimum. The actuality of actual things and their relations, according to both early and Critical writings, is grounded by God's creative representation. We seek a model of the possibility of things and relations in a merely possible world. Let us apply Kant's early model of the ground of the possibility of things in a world. This possibility is grounded by realities actually exemplified by the ens realissimum. A crucial question remains: what grounds the possibility of the relations within merely possible worlds?

It is tempting to think that Kant can argue here that the possibility of merely possible relations may be grounded simply on the fact that God could but does not represent things as standing in these relations. However, the suggestion that God 'could' do this turns out to be problematic. For one thing, the Critical Kant sometimes appears to endorse a version of Leibnizian optimism. The Pölitz lecture transcript claims that the product of a divine will (Wille) 'will be (wird) ... the most perfect world' (28: 1061). This 'will be' is naturally read as asserting that God must create the most perfect world. Combined with $K U$ §76's limit of intuitive representation to what is actual, this would introduce a key sense in which God could not represent, because he could not create, things in merely possible relations. If God must create the most perfect world, then the actual world, comprising actual things and their actual relations, is that world. Now Kant sometimes suggests a weaker position, on which God indeed must create 'only what is in conformity with his highest understanding', but on which it is undecided whether what is created must be the best (28: 1068; cf. Adams 1972). Yet even this view, which I think is closer to Kant's considered one, fits uncomfortably with the proposed solution. For whatever world 'conforms to God's highest 
understanding', the demand that God must create that world combines with KU §76 to suggest that God cannot really represent things standing in different relations. At least this is so assuming that whatever world 'conforms to God's highest understanding' does so necessarily. Whether this attractive modal assumption of 'the necessity of what is best' can be rejected raises thorny theological and modal issues I would rather avoid here. ${ }^{20}$ What I will now propose goes a way towards avoiding such difficulties.

My proposal may be described as a Kantian twist on Leibniz's 'per se possibility' strategy according to which a world may be 'possible in its nature, even if it is not possible with respect to the divine will' (Leibniz 1985a: 289/1989: 21). In particular, I suggest Kant can maintain that the possibility of merely possible causal relations between possible things in themselves is grounded by the natures of those things themselves. This ground will include: (i) that the nature of each thing is such that it can enter into real causal relations with others; and (ii) that no metaphysical repugnance obtains between natures of relevant things preventing the possible relations. Although (ii) may seem to reiterate (i), Kant's early writings see a metaphysical distinction here. In his True Estimation of Living Forces (1747), he proposes that substances may fall into distinct classes distinguished by different essential forces ${ }^{21} \mathrm{He}$ also argues that substances may be capable of interacting only with those of their own class ('acting in accordance with the same law'). In that case, a substance can satisfy (i) but fail to satisfy (ii) with respect to substances of another class due to a 'cosmological repugnance' that obtains between those of different classes.

Three clarifications of this proposal are needed. First, the conditions (i) and (ii) are intended to express necessary material conditions for the real possibility of merely possible relations in the spirit of Kant's own actualism (see section 4.1 above), which, crucially, can be satisfied even in the face of $K U$ \$76. Whether the conditions are sufficient material grounds is another matter. I take Kant's view to be that such sufficiency always involves a certain inscrutability connected with the root of real contingency. Second, condition (ii) concerns metaphysical repugnance arising from the per se nature of things in themselves that precludes real interaction. We can conceive of other forms of metaphysical repugnance. One is an 'existential' repugnance on which one finite substance simply cannot coexist with another. Kant's early writings argue that a finite substance cannot in virtue of its mere existence give rise to an effect in another (ND, 1: 412-13; MSI, 2: 407). That a finite substance's mere existence has no causal bearing on another suggests, although certainly does not entail, that it has no such existential bearing and will not exclude the existence of another. Of course, Kant's Critical philosophy must remain diffident regarding existential as well as other conceivable repugnancies among things in themselves. ${ }^{22}$ Third, roughly the same model just proposed for relations between possible things in themselves can be extended to coexistence of realities within merely possible things. That is, the ground of possibility will be located in those realities themselves, and relevant metaphysical repugnancies will be those arising from the nature of those realities which prevent their coexistence.

Let me underline a point that is essential to solving the problem posed by KU §76: on my proposal divine representation does not ground the possibility of relations of things in themselves. At least it does not do so directly; there may be indirect involvement insofar as God's representation exemplifies certain realities whose natures fix which relations are possible. The crucial point is that the possibility of relations does 
not require that those relations be the object of God's representation. Indeed this point extends to the possibility of actual relations in our world: the possibility of these relations is grounded by the nature of things themselves, while God's creative representation simply gives them existence.

Note that my proposal departs from Chignell's prominent interpretation of Kant's modal proof. On his reading, Kant's ens realissimum grounds via exemplification not only the possibility of the realities of substances but also of their relations. Thus, 'having phenomenal red as a quality of consciousness' and 'being omnibenevolent' can be co-instantiated, whereas 'being conscious' and 'being extended' cannot, because God co-exemplifies the former realities but not the latter (Chignell 2012: 656). I see good textual reason to reject this interpretation in Kant's explanation that the materials of possibility 'contain within themselves an extraordinary adaptedness to harmony; the essences of these materials themselves contain within them a harmony with a whole' (BDG, 2: 100). In other words, Kant explicitly says, as I propose, that possible relations are grounded by the essences of realities themselves, or what is 'contained within themselves'. My model is also philosophically preferable, insofar as it removes the Spinozistic threat posed by $K U$ §76, while avoiding a dire Spinozistic consequence of Chignell's reading. On his reading, the possible co-instantiation of impenetrability and extension (for example) entails that God actually exemplifies both extension and impenetrability (2012: 664-5). The reader may of course wonder why the nature of realities grounds some possible relations while excluding others. Kant's view, I believe, is that no further answer can be given here. I do not find this less mysterious than the proposal that relations are allowed or excluded simply by the ens realissimum co-exemplifying some combinations. I submit that a proposed residual inscrutability accords better with Kant's general posture, which is never to furnish a fully reductive analysis of real contingency.

Consider again my toy analogy of the 'deity' who is the 'ens realissimum' with respect to all possible desserts. The actuality of an actual chocolate chip cookie is grounded by this 'deity of desserts' representing and thereby giving existence to the mixture of its ingredients. The possibility of these ingredients is grounded by the 'maximal' versions of ingredients this deity exemplifies. On the present proposal, the possibility of ingredients of a merely possible brownie is grounded in the same way, that is, by the maximal versions the deity exemplifies. Moreover, the real possibility of the mixture of the brownie's ingredients is grounded by the nature of these ingredients. This includes the fact that there is no metaphysical repugnance of natures that would prevent these ingredients from mixing (in the way, say, density and polarity of oil and water prevent this). Given this ground, the necessary conditions for the really possible existence of our merely possible brownie are met; and these conditions lie in something actual, as Kant's modal actualism demands.

I return now to the problem of merely possible worlds of things in themselves. On my proposal, the conditions that must obtain for these worlds to exist likewise find their ground in something actual. The possibility of the things in themselves comprising such worlds is grounded by the realities that the ens realissimum exemplifies. The possibility of internal and external relations of such worlds is grounded by the nature of the realities instantiated in them. These realities are themselves either exemplified by the ens realissimum or made possible by what the ens realissimum exemplifies. My proposal thus furnishes Kant with a modal metaphysics of really possible worlds that 
is logically consistent with God not representing such worlds. It is, furthermore, a theory developed entirely out of Kant's own philosophical materials. ${ }^{23}$

I noted in section 2 that Kant's commitment to human freedom ultimately presupposes that there are really possible worlds of things in themselves in which an agent's moral character is other than it actually is. So far, I have argued in relatively general terms that Kant has the philosophical resources for a theory of such really possible worlds consistent with $K U$ §76. It is worth considering explicitly, if briefly, how he will account for merely possible moral characters in particular. A moral character, as he conceives of it, rests on an agent's choice to subordinate morality to happiness or vice versa. Any actual moral agent must possess reason and free will. Since any actual moral agent possesses both, their metaphysical grounds in God will be available to ground an actual agent's existence in merely possible worlds in which she makes different choices. According to Kant's early proposal, the grounds in question must include psychological realities exemplified by the ens realissimum, namely God's reason and will (BDG, 2: 88-9; cf. V-Phil-Th/Pölitz, 28: 1049-51). Even granting, then, that God does not represent the merely possible agent or her possible choices, the theory I have sketched can ground their real possibility. The merely possible agent's choice will, of course, affect not only her own character but the broader mental and physical landscape of the possible world in which she exists. Fortunately, as we have seen, Kant's resources to account for such mere possibilities extend readily to such broader features of possible worlds.

\section{Divine omniscience}

I have shown that $K U$ §76's account of divine representation is in fact consistent with Kant's ironclad commitment to the real (mere) possibilities presupposed by his theory of human freedom. We still face however what appears an insurmountable philosophical problem. Once we allow that $K U \$ 76$ offers a theory of divine representation, and allow that Kant affirms real mere possibilities, we have already denied that Kant's God represents and thus knows every truth. For some readers, this abandonment of so-called logical omniscience requires dismissing $K U$ §76, or denying it has to do with divine representation. Neither approach seems to me plausible or satisfactory. There is also far more to be gained both from an interpretative and philosophical perspective by squarely facing up to the difficulty $K U \$ 76$ poses in this respect. I will argue in this section that the proposed model of mere possibility is consistent with a model of divine omniscience that fully acknowledges the claims of $K U \$ 76$. The model is unorthodox but not philosophically unprecedented, and is of interest in its own right.

According to my proposal, divine omniscience as Kant's mature philosophy understands it does not require that God represents everything; in particular, it does not demand that God represent merely possible worlds. Though this is an unorthodox view, it is not without historical precedent. To begin to motivate it, consider by way of analogy the divine attribute of omnipotence. On Descartes' interpretation, a notoriously extreme one, omnipotence is the power of the divine will to do literally anything, including to 'make a mountain without a valley, or bring it about that 1 and 2 are not 3' (Descartes 1991: 359). Modern thinkers responded to Descartes with a range of weaker interpretations of omnipotence, as a power to do anything in some sense 'really' possible, where the latter is spelled out as consistency with logical and 
sometimes moral constraints. Leibniz, for instance, argues that God's will is subject to a moral necessity, insofar as 'metaphysically speaking, [God] could have chosen or done what was not the best; but he could not morally speaking have done so' (Theodicy \$234 (Leibniz 1885: 256/1985b: 271)).

When Kant defends a version of Leibnizian optimism in early work and late lectures, he follows Leibniz on this point. We read, 'God cannot decide otherwise than he does'; God decides 'only in conformity with his highest understanding' (V-Phil-Th/Pölitz, 28: 1068). Such restriction on what God can really do is not seen as limitation but an expression of his true freedom. In explicating this and all divine attributes, Kant wishes to proceed via negationis, by the method of negation: we must 'leave out everything imperfect and negative and ascribe to God the pure reality left over' (28: 1021). Our own ability to decide in opposition to moral demands is presented as a deficiency relative to divine freedom, it represents 'a lack of freedom in the human being' (28: 1068). Kant repeatedly insists that all such 'limits must be left out and only the pure reality which is left over ascribed to God' (28: 1022). Only in this way will we attain a conception of power congruent with the 'dignity of the divine nature' $(28: 1053,1057)$.

Consider now the results of applying Kant's method to the attribute of omniscience. Insofar as possession of a representation entails limitation, Kant requires it 'be left out' of God's knowledge. Again, this approach is hardly unprecedented. Many scholars have taken divine impassibility to be inconsistent with knowing what it is like to experience physical pain or, say, phenomenal redness. ${ }^{24}$ Some readers have even suggested that Kant's God will not represent space and time, insofar as both are essentially connected to our cognitive finitude (see Brewer and Watkins 2012). Our problem however concerns mere possibles. In what way might these be an inappropriate object of God's cognition? What limitation is involved in representation of mere possibility? In $K U$ §76, Kant offers one theoretical answer, and at least suggests a second broadly practical one.

His first answer argues that the distinction we draw between actuality and possibility arises from the fact that our cognition requires 'two entirely heterogeneous elements', namely 'understanding for concepts and sensible intuition for objects corresponding to them' (KU, 5: 401-2). In our mere thought of an object, we do not know its actuality, but accomplish only a "positing of the representation of [that] thing with respect to our concept'. Now the theological tradition treats this discursive or conceptual character of human knowledge as a mark of limitation, and Kant agrees. That our discursive understanding can make no valid inference from possibility to actuality, he argues, does not show that this rule holds 'for objects in general'. Precisely at this point he introduces the intuitive intellect as an intellect that does not know through concepts, and for which it consequently holds that 'all objects [it] cognizes would be' (5: 403). It is indeed by 'leaving out the limitation' of discursive cognition that Kant is led to his qualification of the omniscience that could belong to such an intuitive intellect.

Immediately after this restriction of the intuitive intellect's cognition to what is actual, $K U$ §76 turns back to freedom. Kant asks us to consider a free cause in the 'intelligible world' that is not subject to imperatives because it necessarily 'corresponds completely with the moral law' (5: 404). Here he reiterates his important doctrine that "no imperatives hold for the divine will and in general for a holy will: the "ought" is out of place here, because volition is of itself necessarily in accord with the law' (GMS, 4: 414). 
Our limited freedom, by contrast, is marked by the fact that we can and do fall away from morality, so that 'what necessarily should happen often does not' (KU, 5: 403). Now KU $\$ 76$ has just defined the intuitive intellect as one for which 'all objects [it] cognizes would be'. In pivoting immediately to a divine will that necessarily avoids deviations from morality, Kant at least suggests a second sense in which we might consider representation of possibles a limitation to be excluded from divine knowledge. We can get at the point by reflecting on the deliberative character of our own practical reasoning. One expression of our limitation is our need to represent alternatives before settling on what is best. We can illustrate this point with another analogy, that of an amateur versus expert bartender. Presented with gin, vermouth, Campari and an orange peel, the amateur bartender painstakingly reflects on a range of possibilities in order to settle on a decent drink (the chilled vermouth, the olive-less martini or what have you). The expert bartender, by contrast, immediately sees only the best drink that can be made from these (the Negroni) - and this is indeed an expression of expertise. She does not need to weigh options to arrive at the best; she does not even notice them.

In the same way, I suggest, we might seek to square $K U$ §76 with an unorthodox but coherent theory of divine omniscience if we read Kant as suggesting that God's very lack of limitation favours a view of God as representing only what conforms to his highest understanding. This suggestion can find some independent support in other writings. Kant already insists in early work that God's 'infinite understanding' does not 'compare' 'in order to establish conclusions' (ND, 1: 405). We are also told that 'attention, abstraction, reflection, and comparison are only aids to a discursive understanding', they are all 'beneath the dignity of the divine nature' (V-Phil-Th/Pölitz, 28: 1053). If representation of alternatives serves no purpose for a perfect agent, we should expect Kant's negative theology - expressly spartan and informed primarily by moral considerations - to insist that such representations 'must be left out' of the divine intellect.

To a reader who finds such a weakening of logical omniscience difficult to accept, a few points are in order. First, the imputed theory of divine knowledge, while unorthodox, was apparently not without precedent among German predecessors. Mogens Lærke (2007: 6-7) has argued vigorously and in detail that Leibniz's early Confessio Philosophi (1672/3?) differs sharply from Leibniz's mature theology in affirming a very similar theory, namely that 'God conceives only the best'; God does not 'deliberate and compare options, but ... simply wills and produces the best'. Lærke is also acutely aware that he imputes this theory of divine knowledge as a reading of Confessio's reference to God as 'all-knowing'. My proposal is that $K U$ §76 places Kant close to Lærke's early Leibniz in this regard.

Some further evidence in support of the proposal is found in Kant's otherwise puzzling determination of omniscience in his own moral theology. He argues that the God of moral theology must be omniscient 'so that [he] cognizes the inmost dispositions and [our] moral worth' (A815/B843; cf. KU, 5: 444). Commentators have rightly objected that divine knowledge of our actual moral dispositions, however exact and complete, does not require anything as strong as traditional logical omniscience (see e.g. Hogan 2014: 48). Kant's official deduction of omniscience, if interpreted as logical omniscience, thus leaves a gap analogous to the gap Hume famously locates in the design argument's deduction of God's omnipotence. However, an alternative reading is now available, on which Kant's moral argument does not leave any such 
gap at all. On my proposal, he never meant to deduce anything as strong as logical omniscience, but only a more restricted conception of omniscience - one sufficient for the attainability of the highest good. Kant's moral theology does require that God can represent the degree to which an agent's moral disposition falls short of a perfect will, so that the agent's happiness can be made proportionate with her moral goodness. It is far from clear on reflection, however, that this requirement entails that God represent mere possibilities. If that is correct, my proposal is consistent with the model of divine representation emerging in $K U$ \$76.

Let me conclude this section with a reminder of the difficulty motivating it. We have already abandoned logical omniscience in accepting, as I believe we must, that $K U \S 76$ is meant as a theory of divine representation. We can throw up our hands and simply insist that Kant has painted himself into a theological corner. There are however reasons to regard Kant himself as open to the admittedly puzzling possibility that the divine knowledge demanded by moral theology is consistent, or at least not demonstrably inconsistent, with a conception of God's intellect on which 'all objects [God] cognizes would be' (5: 403).

\section{Objections and replies}

\section{I Competing texts}

According to a first objection, my proposed theory of omniscience is not the Kantian theory we find on offer in a passage from the second Critique:

[T] o say this world was possible only through a God ... we would have to cognize this world as the most perfect ... and, in order to do so, cognize all possible worlds ... (so as to be able to compare them with this one), and would therefore have to be omniscient. (5: 138-9; cf. MpVT, 8: 256; V-Met-K2/Heinze, 28: $792-3)^{25}$

This passage appears to affirm the mature Leibnizian view that God's omniscience involves cognition of every possible world; furthermore, that this is needed to compare worlds and determine which world is best (and in that sense, conforms to God's highest understanding).

There are, in response, strong reasons to reject this reading of the cited text. First, we have noted Kant's insistence that God does not engage in acts of comparison. Charity thus dictates that we interpret him carefully in passages suggesting otherwise. This caveat is especially helpful here. On a closer reading, Kant refers to a kind of omniscience beings like ourselves would need to prove God's existence 'by sure inferences from knowledge of this world'. For us to infer that the world is possible only through God, Kant explains, 'we [NB] would have to cognize this world as the most perfect whole possible etc'. What is at issue here is thus not God's omniscience, but some finite analogue to it.

It is worth emphasizing here that the account of omniscience developed in the last section is not meant as alternative to some canonical Kantian theory, as though that were found elsewhere in Critical texts and given up in $K U$ §76. In fact, Kant writes very little on the topic, and what he does say does not obviously require a theory distinct from the one proposed. The focus of remarks on omniscience in all three Critiques is a 
practical demand on God's knowledge arising from moral theology. As we have seen, Kant infers omniscience so that 'what is inmost in our dispositions ... is not hidden from him' (KU, 5: 444). This is the knowledge Kant thinks is needed for the possibility of his 'highest good'. Insofar as the divine mind represents the actual world, as it does according to $K U$ §76, I submit it can represent our moral stirrings, motives and intentions (V-Phil-Th/Pölitz, 28: 1012). Note that Kant will not allow that God 'compares' our actual motives with possible ones to render moral judgement. Any such comparison, he insists, is beneath God's dignity, and moral theology does not obviously require more than knowledge of what our stirrings, motives and intentions actually are, in this world.

\subsection{God's knowledge of our knowledge}

According to a second objection, my proposed solution is inconsistent with the fact that we represent mere possibilities. The basic idea here is that God enjoys a kind of privileged maker's knowledge of his creation, knowing not just every hair on our head but presumably every representation within it too, thus including those of mere possibility. The view that God fails to represent mere possibility is then unsustainable and $K U$ §76 indefensible.

A first response is that Kant is no worse off under my proposal than on the orthodox view mentioned earlier, since orthodoxy regarding divine impassibility naturally suggests that God cannot represent what it is like to experience physical suffering. ${ }^{26}$ The present objection threatens to prove too much, in other words, if maker's knowledge is equally taken to rule out God's failure to represent pain. ${ }^{27}$ It is of course another question how God avoids such representation, if he represents everything that is actual. Here I can merely gesture towards one response available both to Kant and the proponent of the view that God does not represent pain. Both might counter the present objection by drawing on the familiar Cartesian distinction between the reality a representation possesses in virtue of its content (its 'objective' reality) and the reality it possesses in virtue of being a representation (its 'formal' reality). Armed with this distinction, Kant might coherently deny that the divine intellect represents mere possibility, while allowing that God knows our representations of such possibility in the sense of representing the formal reality of these representations.

\subsection{Countervailing pre-Critical evidence?}

A final objection challenges my use of Kant's early cosmology and theology to support my proposed account of merely possible worlds. The objection notes a text from Kant's pre-Critical theistic proof that appears inconsistent both with my proposal and with $K U$ §76 more generally:

[W] ho can deny that in [God's] representation [of things which do not actually exist] ... not a single determination [is] missing, though existence is not among them, for the Supreme Being cognizes them only as possible. (BDG, 2: 72; cf. 2: 74) 
Here Kant appears to espouse a familiar picture on which God represents both actual and nonactual objects. This raises the question: How can Kant's earlier views help solve a problem founded on the rejection of those very views? ${ }^{28}$

Note first that the passage occurs in the context of a thought experiment contrived for the purpose of motivating Kant's doctrine that existence is not a real predicate. His argument is addressed to contemporaries in the Leibniz-Wolff-Baumgarten tradition who admit God's representation of mere possibles. We should be cautious about reading the passage as an official presentation of Kant's own theology. I am nevertheless willing to grant that Kant's pre-Critical work plausibly regards God as representing merely possible worlds. This point does not touch my central argument, which is that his early writings do not make divine representation the ground of such worlds or mere possibility more generally. ${ }^{29}$ Kant does not explicitly develop any theory of merely possible worlds in his early writings, but I have argued that his model of the ground of the actual world and the ground of possibility in general strongly suggests one not resting on divine representation. For this reason, his early cosmology and theology remains of tremendous value in developing a solution to the puzzle arising from his writings of 1790.

\section{Conclusion}

In this essay, I have proposed a new solution to the notorious difficulty posed by Kant's discussion of the intuitive intellect in $K U$ §76. While the positive interpretative proposal advanced above is a radical, and some will say scandalous, departure from an entrenched wisdom concerning Kant's philosophical theology, it is in another sense extremely conservative. It is remarkable that it solves all the problems with which we began, utilizing a modal theory offered by Kant himself and remaining fully consistent with his presentation of his philosophical theology across the gamut of pre-Critical and Critical texts. I am, in the final analysis, undecided whether the proposal correctly captures Kant's meaning in $K U$ §76. I do however believe, and I have argued in detail, that on philosophical and textual grounds it merits a place among the serious contenders. ${ }^{30}$

\section{Notes}

1 Abbreviations: Der einzig mögliche Beweisgrund zu einer Demonstration des Daseins Gottes (BDG); Grundlegung der Metaphysik der Sitten (GMS); Kritik der praktischen Vernunft (KpV); Kritik der Urteilskraft (KU); Die Metaphysik der Sitten (MS); De mundi sensibilis atque intelligibilis forma et principiis (MSI); Nova Dilucidatio (ND); Metaphysik Mrongovius (V-Met/Mron); Religionslehre Pölitz (V-Phil-Th/Pölitz). Translations are either original or (occasionally modified) from The Cambridge Edition of the Works of Immanuel Kant (general editors Paul Guyer and Allen W. Wood, 1992-). The Critique of Pure Reason is cited by A/B pagination, other works by the Akademie edition's volume/page number (Berlin: de Gruyter and predecessors, 1900-).

2 It is 'absolute necessary' that we judge that 'things can be possible without being actual' because our discursive concepts have neither a logical nor extra-logical connection to existence (cf. Leech 2014). 3 See e.g. B71-2, 145; Prolegomena, 4: 355-6; KpV, 5: 123, 137; Religion, 6: 67; MSI, 2: 397.

4 This implication assumes reality's correspondence to God's representation (cf. Kohl 2015, Marshall 2018, Winegar 2018).

5 Unlike the imperfect human will, God never falls short of the standard prescribed by the moral law. In that sense divine freedom does not on Kant's view presuppose mere possibilities (cf. Pereboom 2006, Wood 1984). 
6 As Adams (1994: 46-50) has noted, the possible worlds semantics of contemporary analytic philosophy is in many respects alien to Leibniz, even if his philosophy was a major stimulus to its development. While Kant does speak a good deal of possible worlds, the caveats noted by Adams apply equally to his (Leibniz-inflected) use of the term. This point is presupposed throughout. The idiom of possible worlds employed here is readily translatable into one of alternative real possibilities for the cosmological order employed extensively in Kant's writings.

7 See Leibniz’s Monadology (§§43-4), Wolff’s German Metaphysics (§973), Baumgarten’s Metaphysica (§8678). Cf. Messina 2016: esp. 231-2, 235.

8 See Stang (2016) and Abaci (2019) for two in-depth discussions of Kant's notion of real possibility. 9 While I am quite confident on this point, notice that no great harm is done if I am mistaken here. A solution that can accommodate mere real possibilities can also accommodate mere logical possibilities. 10 For present purposes we may ignore complications such as time-indexing of possibilities. As the formulation suggests, the real possibility relation at issue treats appearance-worlds involving alien sensible forms as inaccessible from the actual world of appearances, though Kant sometimes countenances their possibility in a weak sense. Regarding the use of 'worlds' here, see the caveat in note 6.

11 See note 7 above.

12 As one would expect given this fact, Kant's post-KU account of freedom continues to invoke mere possibility (see Religion, 6: 50n; cf. 6: 41-9).

13 My thanks to Des Hogan for discussion of these points. This is just a selection of evidence against the central thesis of Abaci (2019) which advances from a positivist reading of the Postulates to the view that Kant is an amodalist about things in themselves. Further evidence against amodalist approaches (e.g. Kohl 2015, Stang 2016) includes Kant's practical proof of the real possibility of God, the immortal soul and freedom; Kant's clear commitment to noumenal grounding of the empirical realm; and most importantly, his theory of human freedom, which demands mere possibilities at the level of things in themselves.

14 Here I agree with Adickes, Adams, Stang and Chignell that the Critique's epistemic qualification regarding Kant's early argument (A580/B608, A582-3/B660-1) is gravely misunderstood if taken as dogmatic rejection of its conclusion that possibilities in fact have their ultimate metaphysical ground in God. 15 See Stang (2016) and Chignell (2012) for recent interpretations of the Critical philosophy as upholding modal actualism. Aside from the 'noumenal amodalism' proposal rejected above, Abaci (2017) seeks a weaker reading of Kant's mature empirical actualism, namely as holding only that cognition of real possibility must be grounded by empirical cognition of actuality.

16 Kant's 'fiery body' example with its 'extension, impenetrability, force, and I know not what else' is offered as part of his general effort to bring the unavoidably abstract nature of his theistic proof 'closer to the more ordinary concepts of sound understanding' (BDG, 2: 80). For purposes of the example, we are to 'suppose' that extension is unanalysable, i.e. a fundamental reality. This is a mere supposition however, since Kant immediately proceeds to argue that extension cannot be exemplified by God (2: 85-9; cf. VPhil-Th/Pölitz, 28: 1021-2). Kant is understandably reluctant to specify the divinely exemplified maximal realities, especially any of a wholly cosmological character. His early proof does argue for two such psychological realities, understanding and will (2: 87-9; cf. 28: 1049-51), and God's traditional attribute of omnipotence, referenced above, is a plausible candidate for derivative cosmological realities like force (cf. 28: 1021-3). But in general, Kant's account must remain abstract regarding maximal realities and their natures; my reconstruction follows suit.

17 Kant's mature philosophy argues that God's creation must be 'a creation of things in themselves' ( $\mathrm{KpV}$, 5: 101-2; cf. V-Met/Mron, 29: 849-54). The world of appearances never constitutes a whole insofar as it exists only in 'the regressive series of representations' (A505/B533). On the details of Kant's 'theoreticopractical' justification for his remarkably committal mature metaphysical model of divine and secondary causation, see Hogan (forthcoming); cf. Insole (2014). Ameriks (1992) offers further useful analysis of continuities between pre-Critical and mature metaphysical views.

18 This pre-Critical model is echoed at B72, 139, 145; MSI, 2: 397; Briefe, 10: 130; V-Met/Mron, 29: 796-7, 833; KU §§76-77; V-Phil-Th/Pölitz, 28: 1061, 1065; cf. Messina (2016: 239).

19 See previous two notes.

20 On Leibniz's struggles with this issue, see Adams 1994: 23ff. Note my worry above is not that KU §76's apparent exclusion of mere possibility is inconsistent with optimism. If the actual world is the only possible world, it is by default the best possible. The worry is rather the tension between (i) the proposal that 
God could represent non-actualized world X, and (ii) optimism's seeming result that God must actualize a particular world Y, together with (iii) KU §76's implication that God represents only what is actualized. 21 See True Estimation, 1: 22-5. For helpful discussion of these passages, see Hogan (2005: ch. 1).

22 True Estimation holds that considerations of plenitude give God reason to create multiple worlds partitioned on the basis of substances' essential forces. Since his cosmologically repugnant substances in distinct actual worlds all exist, they are not existentially repugnant. Kant soon abandons this early plentitude view in favour of an orthodox view that God creates one world (MSI, 2: 408). Note that if God must create only one world, as optimism requires, True Estimation's relation of cosmological repugnance gives rise to a relation of existential repugnance. The latter is however mediated by God's reasons, whereas my conditions concern repugnance arising from the per se nature of substances (roughly, their "narrow concept' as in chapter 1 of Adams 1994).

23 Since our challenge arises from Kant's affirmation of mere possibilities not represented by KU §76’s intuitive intellect, whoever insists on the so-called 'intellectualist' reading of his modal theory has already given up the game. For on the intellectualist reading (see e.g. Hoffer 2016, Yong 2014), Kant's ens realissimum grounds possibilities by representing them, thus there are no possibilities not represented by God. Faced with $K U$ §76, the following modified version of the intellectualist reading can nevertheless accommodate mere possibilities by utilizing my strategy above. It says: (i) God's representation is the ground of the actual world, both as regards its actuality and possibility; (ii) God's representation also grounds merely possible worlds, not by directly representing them, but by providing materials for their possibility. To illustrate (ii), return to my dessert analogy. On the modified intellectualist theory, the (actual) cookie's actuality and possibility is grounded by the dessert-deity's representation of its mixture of ingredients. By representing these ingredients, the deity also grounds the possibility of the (nonactual) brownie's ingredients, since these are a subset of the former. The possibility of the mixture of ingredients in the brownie is however grounded by the ingredients' natures themselves. The non-actual brownie is thus possible, even though unrepresented, in virtue of what is represented. In the same way, merely possible worlds, though not represented, are really possible in virtue of what God does represent. Potential drawbacks for this modified application of my strategy include that alternate possibilities are posterior to and constrained by the created world.

24 Zagzebski's (2013: 45) case for 'omnisubjectivity' as a divine attribute acknowledges its incompatibility with impassibility; cf. Creel's (1986: 129) reconciliation of impassibility with divine omniscience, which also concedes that it is in principle impossible for any being to know directly the subjectivity of another'.

25 Another seemingly problematic passage claims that God 'must be omniscient in order to cognize my conduct even to my inmost disposition in all possible cases and throughout the future' ( $\mathrm{KpV}, 5: 140)$. 'All possible cases' is however readily construed as an abbreviation for 'all possible cases that occur', i.e. now and throughout the future.

26 Lecture transcripts report Kant as arguing that 'vengeance cannot be thought in God, because vengeance always presupposes a feeling of pain impelling one to do something similar to the offender' (V-PhilTh/Pölitz, 28: 1086).

27 Kant will be anxious to avoid saying that ensuring the distribution of happiness to virtue requires God to represent the suffering agents' experience in their moral lives. He does hold that virtue is 'assess[ed] only by the magnitude of the obstacles that the human being himself furnishes through his own inclinations', so that his moral theology will require that God somehow represent struggles an agent endures for the sake of morality (MS, 6: 405).

28 BDG 2: 72, appears to uphold the traditional view that God's will (rather than intellect) grounds actuality. I note that Kant's own definition of God's will in lecture transcripts suggests greater continuity between early and late views here: 'It is the divine understanding determining God's activity to the production of the objects he represents' (V-Phil-Th/Pölitz, 28: 1065, 1061).

29 It has been suggested to me that ND, 1:413-4, maintains that possible relations between substances are grounded by the 'schema of God's understanding'. That text however speaks only of God's productive schema; it says nothing about a non-productive schema grounding the possibility of things and/or relations. Here I agree with Messina (2016: 239).

30 I am grateful to Andrew Chignell, Michelle Kosch, Maya Krishnan, Florian Marwede, James Messina, Derk Pereboom, Eric Watkins, Marcus Willaschek, Allen Wood, two anonymous referees for Kantian Review and audiences at Cornell, Goethe-Universität Frankfurt am Main, Harvard, Indiana University 
Bloomington, Johannes Gutenberg-Universität Mainz and Princeton for helpful feedback on earlier versions of this article. Special thanks to Des Hogan for reading multiple drafts and providing valuable comments and suggestions.

\section{References}

Abaci, Uygar (2017) 'Kant, the Actualist Principle, and the Fate of the Only Possible Proof. Journal of the History of Philosophy, 55(2), 261-91.

Abaci, Uygar (2019) Kant's Revolutionary Theory of Modality. New York: Oxford University Press.

Adams, Robert M. (1972) ‘Must God Create the Best?'. Philosophical Review, 81(3), 317-32.

Adams, Robert M. (1994) Leibniz: Determinist, Theist, Idealist. New York: Oxford University Press.

Adams, Robert M. (2000) 'God, Possibility, and Kant'. Faith and Philosophy, 17(4), 425-40.

Ameriks, Karl (1992) 'The Critique of Metaphysics: Kant and Traditional Ontology'. In Paul Guyer (ed.), Cambridge Companion to Kant (Cambridge: Cambridge University Press), 249-79.

Brewer, Kimberly, and Watkins, Eric (2012) 'A Difficulty Still Awaits: Kant, Spinoza, and the Threat of Theological Determinism'. Kant-Studien, 103(2), 163-87.

Chignell, Andrew (2009) 'Kant, Modality, and the Most Real Being'. Archiv für Geschichte der Philosophie, 91(2), 157-92.

Chignell, Andrew (2012) 'Kant, Real Possibility, and the Threat of Spinoza'. Mind, 121(483), 635-75.

Creel, Richard (1986) Divine Impassibility. Cambridge: Cambridge University Press.

Descartes, René (1991) The Philosophical Writings of Descartes, vol. 3. Trans John Cottingham, Robert Stoothoff, Dugald Murdoch and Anthony Kenny. Cambridge: Cambridge University Press.

Förster, Eckart (2012) The 25 Years of Philosophy. Trans Brady Bowman. Cambridge, MA: Harvard University Press.

Franks, Paul (2005) All or Nothing: Systematicity, Transcendental Arguments, and Skepticism in German Idealism. Cambridge, MA: Harvard University Press.

Hoffer, Noam (2016) 'The Relation between God and the World in the Pre-Critical Kant'. Kantian Review, 21(2), 185-210.

Hogan, Desmond (forthcoming) 'Kant's Theory of Divine and Second Causation'. In Brandon Look (ed.), Leibniz and Kant (Oxford: Oxford University Press).

Hogan, Desmond (2005) 'Rationalism and Causal Realism in Kant's Metaphysics'. Dissertation, Yale University.

Hogan, Desmond (2014) 'Kant on Foreknowledge of Contingent Truths'. Res Philosophica, 91(1), 47-70.

Insole, Christopher (2013) Kant and the Creation of Freedom. New York: Oxford University Press.

Kohl, Markus (2015) 'Kant on the Inapplicability of the Categories to Things in Themselves'. British Journal for the History of Philosophy, 23(1), 90-114.

Lærke, Mogens (2007) 'Quod non omnia possibilia ad existentiam perveniant: Leibniz's Ontology of Possibility, 1668-1678'. Leibniz Review, 17, 1-30.

Leech, Jessica (2014) 'Making Modal Distinctions: Kant on the Possible, the Actual, and the Intuitive Understanding'. Kantian Review, 19(3), 339-65.

Leibniz, G. W. (1885) Die Philosophischen Schriften, vol. 6. Ed. Carl Gerhardt. Berlin: Weidmannsche Buchhandlung.

Leibniz, G. W. (1985a) Textes Inédits. Ed. Gaston Grua. New York: Garland Publishing.

Leibniz, G. W. (1985b) Theodicy. Trans. E. M. Huggard, ed. Austin Farrer. La Salle, IL: Open Court Publishing.

Leibniz, G. W. (1989) Philosophical Essays. Trans. Roger Ariew and Daniel Garber. Indianapolis: Hackett Publishing.

Marshall, Colin (2018) 'Never Mind the Intuitive Intellect: Applying Kant's Categories to Noumena'. Kantian Review, 23(1), 27-40.

Messina, James (2016) 'The Fate of the World (and Compossibility) After Leibniz'. In Gregory Brown and Yual Chiek (eds), Leibniz on Compossibility and Possible Worlds (Cham: Springer International Publishing), 227-49.

Pereboom, Derk (2006) 'Kant on Transcendental Freedom'. Philosophy and Phenomenological Research, 73(3), 537-67. 
Sedgwick, Sally (ed.) (2000) The Reception of Kant's Critical Philosophy. New York: Cambridge University Press.

Stang, Nicholas (2016) Kant's Modal Metaphysics. New York: Oxford University Press.

Winegar, Reed (2018) 'Kant on Intuitive Understanding and Things in Themselves'. European Journal of Philosophy, 26(4), 1238-52.

Wood, Allen W. (1984) 'Kant's Compatibilism'. In Self and Nature in Kant's Philosophy (Ithaca, NY: Cornell University Press), 73-101.

Yong, Peter (2014) ‘God, Totality and Possibility in Kant's Only Possible Argument'. Kantian Review, 19(1), 27-51.

Zagzebski, Linda (2013) Omnisubjectivity: A Defense of a Divine Attribute. Milwaukee: Marquette University Press.

Cite this article: Brewer, K. (2021). Alternate Possibilities, Divine Omniscience and Critique of Judgement \$76. Kantian Review 26, 393-412. https://doi.org/10.1017/S1369415421000194 